Mila Gadžić, Ph.D.

University of Mostar, Faculty of Economics Mostar, Bosnia and Herzegovina mila.gadzic@ef.sum.ba

\title{
EU PROSPECTS FOR BOSNIA AND HERZEGOVINA: BETWEEN STAGNATION AND GROWTH
}

Recived: October 15, 2018

Accepted: December 10, 2018

\section{Preliminary communication}

\begin{abstract}
The aim of this paper is to point to the specificities of economic and political transformations in Bosnia and Herzegovina (B\&H) and the Western Balkan in the context of economic and political changes in the global environment that can significantly affect the EU accession process. An analysis of the position of $B \& H$ in the group of Western Balkans countries and the perspective of economic growth was conducted by focusing on the political and economic criteria as well as on the current obstacles these countries are facing, specifically, based on their political and economic background and in conditions where external risks are growing.

All these countries are commited to implementing structural reforms because the commitment of all the countries towards Europe, which means convergence towards the European countries and a reduction in the size of the GDP per capita. In order to achieve such long-term goals, it is necessary to implement structural reforms that will result in stimulating production, trade, financial flows and reforming the labor market and the public sector. That is why growth of investment and exports is the main determinant of long-term growth. This paper gives an overview of the basic economic features of B\&H compared with the other countries that belong to Western Balkan region, as well as projections on the certain macroeconomic indicators in the forthcoming period.
\end{abstract}

Keywords: European Union, Bosnia and Herzegovina, Western Balkan, Association, integration, structural reforms, investments, competitiveness, risk, prospects.

JEL: 052 


\section{INTRODUCTION}

Bosnia and Herzegovina is a country that has been for long in the process of political and economic transition towards a market economy with a view to becoming a full member of the EU. However, the process is taking place very slowly and with constant political tensions that make it difficult to implement the necessary structural reforms. In such conditions, the priority is to build a legal state that can ensure political stability and economic growth. A legal state is the main condition, and at the same time it is the backbone of every democratic society. Its main task is to provide legal security with a view to the functional maintenance of the constitutional order, internal security, functional values of the democratic order and fundamental human rights and freedoms on which the EU is built.

The European prospect of $\mathrm{B} \& \mathrm{H}$ is not possible without a new constitution, fully harmonized with the European Convention on Human Rights and Fundamental Freedoms. Only such B\&H will enable the establishment of functional and efficient state institutions with powers that will allow accelerated accession to the European and Euro-Atlantic integration. In the Western Balkans, B\&H is, alongside Kosovo, the worst positioned in the context of the EU accession.

The degree of development of the economic system directly influences political stability, the standard of citizenship, the effectiveness of legal mechanisms, and the quality of relations with the environment. The rule of law system ensures freedom of the people and the individual and their participation in political life, and thus makes the precondition of an economic prosperity. Economic development for the core objective is to ensure self-sustainability, competitiveness, flexibility and ecological sustainability of the economic system of Bosnia and Herzegovina. The achievement of such an emphasized fundamental economic goal is in principle a complex process whose successful implementation depends on the achievement of a large number of smaller and interrelated and dependent sub-goals.

The concept of an open market and export-oriented economy of small countries such as $\mathrm{B} \& \mathrm{H}$ in the long run can ensure its balanced and sustainable development. We must, therefore, be aware that external constraints on the development of $\mathrm{B} \& \mathrm{H}$ economy are great because $\mathrm{B} \& \mathrm{H}$ can not in any sense affect the conditions that govern its environment and the world economy, but can only constantly adapt. This means that it is necessary to achieve the high efficiency of production of $\mathrm{B} \& \mathrm{H}$ economy with the aim of achieving its competitiveness on the world, especially in the European market. Of course, high efficiency is only possible in the market economy.

Many authors dealing with the determinants of economic growth emphasize the importance of strengthening democracy and the rule of law. Thus Barro in his research (1996) argues that the growth rate of real GDP per capita is higher in 
countries where a legal state has been built and with lower national consumption and lower inflation. Strengthening democracy and political rights initially increases growth but accelerates growth when a moderate level of democracy is achieved. Of course, other public policies such as tax policy, pension and other transfer programs and the legislative framework affecting financial markets, labor markets and other markets are important. Significant growth determinants are infrastructure investments, R \& D expenditure, quality of education, and revenue and wealth distribution.

\section{THE MAIN CHALLENGES FACING B\&H TOWARDS THE EU}

Special accession criteria need to be met for the accession process of $\mathrm{B} \& \mathrm{H}$ and the Western Balkans countries to the EU. The three fundamental criteria that are required for accession refer to the Copenhagen criteria set at the Copenhagen European Council meeting in 1993. These are: political, legal and economic criteria. Political criteria imply the stability of institutions guaranteeing democracy, the rule of law, respect for human rights and the protection of minorities. Legal criteria imply the ability to assume membership obligations, including the commitment to the goals of the political, economic and monetary union. Economic criteria imply the existence of a functioning market economy, capable of cope with competitive pressure and market forces.

In addition to the Copenhagen Criteria, potential EU member states have to fulfill the additional criterion (Madrid criteria) set at the Madrid European Council meeting in 1995. This criterion concerns adapting the administrative structure to create conditions for gradual and harmonious integration, skills and the creation of an effective state administration system for the implementation of the acquis communautaire and other obligations deriving from membership in the European Union. The criterion from Madrid is called an administrative criterion.

Western Balkans countries are more advanced in economic reforms than in the rule of law. Based on a new assessment methodology, most countries have only "some level of preparation" in the three areas of the rule of law, including functioning of the judiciary, fight against corruption and fight against organised crime. This is a long way from the "well advanced" state of progress needed for the EU accession. The situation is a bit better with regard to economic reforms, where most countries are "moderately prepared". Bosnia and Herzegovina and Kosovo are lagging behind, being assessed at "an early stage" in this area ${ }^{1}$.

Comprehensive reforms are needed to promote a dynamic private sector. The state must play an important growth-enabling role by providing the rule of law, a stable

\footnotetext{
${ }^{1}$ EBRD, The Western Balkans in transition: diagnosing the constraints on the path to a sustainable market economy, February 2018, pp. 10.
} 
macroeconomic environment and clear rules of the game for businesses. Bosnia and Herzegovina and whole region of Western Balkans lies at the heart of Europe and is surrounded by European countries. However, weak economic performance, combined with political instability and upheaval over recent decades, has left the region lagging behind the EU indicators in terms of prosperity and living standards. GDP per capita in the Western Balkans is on average just one-quarter of the level in the richest EU members in Western Europe. ${ }^{2}$

\subsection{The challenges of convergence towards the $\mathrm{EU}$}

Bosnia and Herzegovina faces high import dependence problems and low export competitiveness, which contributes to a high trade deficit. Inadequate export growth is the result of poor industrial policy and restructuring of the industry sector. That is why economic policies are needed to ensure the restructuring of the real sector of the economy with the aim of strengthening competitiveness. The key objectives of such an industrial policy would be to ensure some reindustrialization of the strongly de-industrialized economy. This could be done through measures that would facilitate the development of new industries and strengthen those sectors that, presently, contribute the largest part of exports. As a result of such movements, the process of the income convergence and catching up with the more developed EU has been extremely slow and has still not reached pre-transition levels of real GDP.

In the exploration of convergence / divergence, Barro has come to the conclusion of convergence, provided that developing countries have the same level of education as developed countries. ${ }^{3}$ Countries in the Western Balkans face a major convergence challenge. Current average GDP per capita for the six countries is only half the average in the $11 \mathrm{EU}$ member states of eastern Europe (EU-11), and just one-quarter of the most advanced western European countries (Chart 1.). The main reason behind this prosperity gap is the lack of appropriate factors and institutions needed for high levels of long-term productivity growth.

\footnotetext{
${ }^{2}$ EBRD, The Western Balkans in transition: diagnosing the constraints on the path to a sustainable market economy By Peter Sanfey and Jakov Milatovic February 2018, pp.3

${ }^{3}$ Barro, R. and X. Sala-I-Martin, 1992. Convergence. Journal of Political Economy, 100(2): 223-251.
} 
Chart 1. Convergence scenario

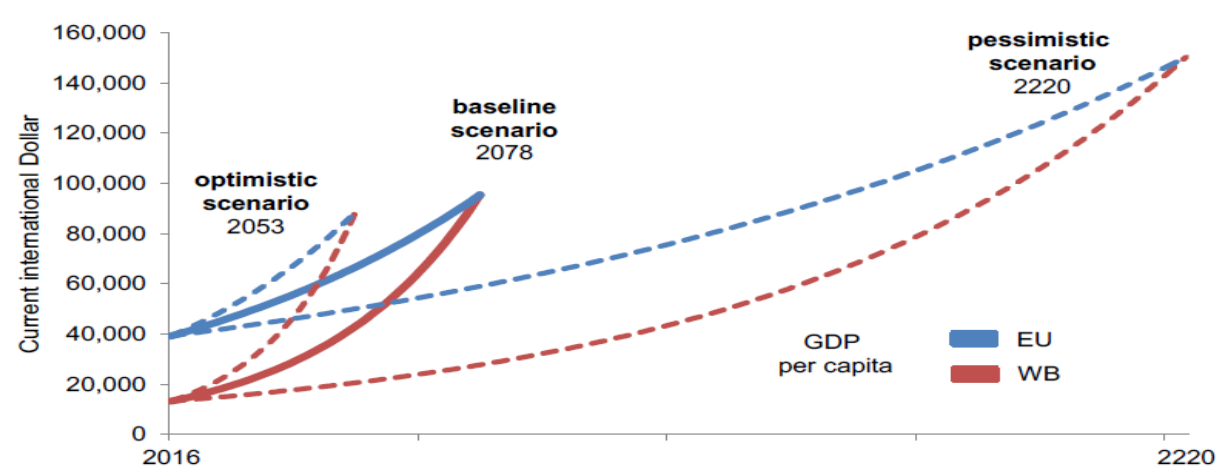

Source: EBRD, The Western Balkans in transition: diagnosing the constraints on the path to a sustainable market economy, February 2018.

Consequently, full convergence with average EU living standards could take many decades. After the global financial crisis, B\&H has significantly lower GDP growth rates compared to the period before the global financial crisis. As a consequence of the slowdown in economic growth, the assumptions for convergence towards the EU countries are worsening. If the economy continues to grow by the current rates of economic growth, it will take more than a decade to reach the EU.

Analyzing the convergence opportunities of the Western Balkans countries towards the EU countries, EBRD has developed several possible scenarios. A baseline scenario, which uses the average growth rates for the period of 2001-16, implies that the WB- 6 region, on average, could achieve the average GDP per capita in the EU in about 60 years. An optimistic scenario, which uses pre-crisis growth rates, would yield catch up with EU living standards in just under 40 years, while a pessimistic scenario, which uses the post- crisis average growth rates, means that catching up takes place after 200 years. The speed of catch up would depend on the pace of addressing the challenges that hamper the region from developing its full potential. ${ }^{4} \mathrm{~A}$ large number of factors may affect the convergence rate of $\mathrm{B} \& \mathrm{H}$ and other Western Balkan countries towards the EU. The most important are however policies that will support faster development of the private sector of the economy, ie a higher level of private investment and job creation, and growth of exports. More efficient policies are needed to stimulate $R \& D$ and innovation, along with better quality reforms of the system of education, that are essential for reducing the present mismatch between demand and supply of specific labor skills. These policies are also closely related to the current EU objectives of a knowledge-based economy. More intensive regional cooperation among the Western Balkan countries - including better coordination of national policies in various areas and

${ }^{4}$ EBRD, The Western Balkans in transition: diagnosing the constraints on the path to a sustainable market economy, February 2018, pp. 4. 
implementation of regional initiatives - is another highly desirable priority for stimulating growth in the medium term. Although the benefits of regional cooperation have been emphasized for a long time, its potentials have not been sufficiently utilized. In addition to increasing intra-regional trade, which, for the most Western Balkan countries, still remains quite important, other forms of regional economic cooperation could also contribute to growth in the areas of $R \& D$, energy, transport or other specific industries.

Bosnia and Herzegovina has made some progress, but is still at an early stage of establishing a functioning market economy. Some improvements of the business environment have been achieved and the financial sector has been strengthened. Key remaining issues are a weak rule of law, a still poor business environment, a fragmented and inefficient public administration and major labour market imbalances, related to a poor education system, weak institutional capacities, and an unsupportive investment climate. In order to support long-term growth, Bosnia and Herzegovina should pay particular attention to: strengthen the political ownership of reforms and the cooperation and coordination among different levels of government; improve the quality of public finances by strengthening its growthfriendliness and improving the targeting of social spending; improve the provision and quality of timely and exhaustive statistics, increasingly applying European and international standards.

Western Balkans countries lag behind the EBRD regional average in terms of progress towards a sustainable market economy. The six qualities are: competitive, well-governed, green, inclusive, resilient and integrated. The results show that the most Western Balkans countries are lagging behind in competitiveness and governance, in common with the rest of the EBRD region. The difference in relation to the EU countries in central and Eastern Europe is much more pronounced, with gaps ranging from 1.3 to 2.0 points.

Table 1. Transition scores for six qualities of a sustainable market economy

\begin{tabular}{|l|r|r|r|r|r|r|r|}
\hline & Competitive & $\begin{array}{c}\text { Well- } \\
\text { governed }\end{array}$ & \multicolumn{1}{c|}{ Green } & Inclusive & Resilient & Integrated & Average \\
\hline Albania & 4.4 & 4.3 & 4.9 & 5.1 & 4.9 & 5.8 & 4.9 \\
\hline Bosnia and Herz. & 4.7 & 3.7 & 4.8 & 4.8 & 5.3 & 5.5 & 4.8 \\
\hline FYR Macedonia & 5.4 & 5.2 & 4.9 & 4.7 & 5.3 & 6.0 & 5.3 \\
\hline Kosovo & 3.4 & 3.7 & 3.8 & 4.7 & 5.1 & 4.9 & 4.3 \\
\hline Montenegro & 4.9 & 5.1 & 5.2 & 5.6 & 5.9 & 5.6 & 5.4 \\
\hline Serbia & 4.9 & 4.4 & 5.8 & 5.2 & 5.6 & 6.4 & 5.4 \\
\hline WB-6 & 4.6 & 4.4 & 4.9 & 5.0 & 5.3 & 5.7 & 5.0 \\
\hline EU-11 & 6.5 & 5.7 & 6.3 & 6.3 & 7.3 & 7.5 & 6.6 \\
\hline EBRD & 4.9 & 4.8 & 5.4 & 5.4 & 5.7 & 6.0 & 5.4 \\
\hline
\end{tabular}

Source: EBRD, The Western Balkans in transition: diagnosing the constraints on the path to a sustainable market economy, February 2018, p. 20. 


\section{STRUCTURAL WEAKNESSES OF THE B\&H}

In order to implement a more efficient industrial policy, B\&H could learn from the current EU measures that aim at the reindustrialization of the EU economy. The Strategy for the Reindustrialization of Europe, launched in 2012, aims at increasing the share of manufacturing from the current $15 \%$ to $20 \%$ of GDP by 2020 . The share of the manufacturing industry in GDP is about 13\% in 2017. The public sector share of GDP is large and it is about $20 \% \%^{5}$. Such a high share of public administration in the B\&H economy reflects the multiple layers of the country's government, including the central government, governments of two entities and the Brčko district, cantonal governments in the Federation of Bosnia and Herzegovina, as well as local administration across the country. It is therefore necessary to take measures to change the structure of the economy. Since the 1990s, deindustrialization has been highly expressed in $\mathrm{B} \& \mathrm{H}$, which is one of the main causes of poor economic structure.

De-industrialization is characteristic of all Western Balkan countries as the logical consequence of changes in countries that have left the socialist system and have begun to build the institutional framework for building a market economy and civil society. The experience of other countries has shown that production, employment, productivity and competitiveness, aggregate demand, real wages and living standards as a whole are inevitably the result of the changes being made. Privatization of state-owned enterprises has led to the dismissal of a number of workers in all countries in order to open up the space for restructuring. In $\mathrm{B} \& \mathrm{H}$, this problem in the context of privatization is less pronounced because of the fact that during the war a large part of the industrial caucus was destroyed.

Even before the war in $\mathrm{B} \& \mathrm{H}$, there was a question of justifying the work and the need for restructuring some of the major industrial systems, such as ironworks, coal mines, chemical combines and others that were built in the former Yugoslavia as a raw material for the development of other republics. As a result of war destruction, market loss and obsolete technology, and later privatization, major industrial systems have ceased to exist. In post-war reconstruction, there was no costeffective investment in their revitalization due to obsolete technology and the need for their transformation, both in organizational terms and in terms of orientation to new production and new technologies. On the other hand, it was necessary to redirect the economic structure to other production, which have the potential for market valuation.

However, $\mathrm{B} \& \mathrm{H}$ has failed to define clear industrial policy and institutional support for industry development. Clear industrial policy is needed to ensure economic

\footnotetext{
5 Agency for Statistics of Bosnia and Herzegovina
} 
growth that can be achieved thanks to the inherited industrial base and tradition in industrial production. In the real GDP structure, expenditures on household final consumption have an impact on the overall economic activity, and average of $79.3 \%$ of GDP, although there has been a recent trend of decreasing the share of this consumption. Expenditure on government final consumption averages $21.5 \%$ of GDP, with the share of this category declining in GDP as a result of more rational public spending. Average gross investment expenditure is $18.6 \%$ of GDP and relates mostly to investments in new fixed assets. Exports in the mentioned period in the structure of GDP are $32.3 \%$, while imports represent $51.6 \%$. The more positive structure of GDP has been recorded in previous years as a result of the increase in the share of gross investment and exports so that their share at the end of the third quarter of 2017 . amounts to $20.8 \%$ and $37.0 \%$, respectively ${ }^{6}$.

\section{SME SECTOR AS THE DRIVER OF THE GROWTH OF THE ECONOMY OF B\&H}

SMEs should be one of the pillars of B\&H's economic development. In this sense, it is necessary to define the overall SMEs development policy in the context of regional and local specificities. Policy development of SMEs should be focused on removing barriers and encouraging environment for the emergence and development of new enterprises. The main question is: how to improve competitiveness od SMEs? The positive business environment and efficient public business support at all levels are the most important factor in the competitiveness of SMEs. Further improvement of economic policy that should be in function of faster economic development and better competitiveness position of $\mathrm{B} \& \mathrm{H}$ economy is necessary. Special attention should be focused on:

- Improving administrative efficiency at the national and regional level,

- Improving business competitiveness through e-business services,

- Providing advisory services to SMEs,

- Creating incentive investment climate,

- Supporting cluster development.

A key factor for SMEs development in specific industries in the developed economies are clusters. They offer a new way of thinking about economic development, giving the new role of business to the governments and institutions. They are development tool that should be recognized by state, entities and local authorities in $\mathrm{B} \& \mathrm{H}$, who should encourage their formation and growth. Clusters are binding factor with similar companies in a particular field and they have to become widely accepted component of national and regional development plans. That process involves a partnership of governments, business and academic communities. That is why B\&H need new policies for the development of SMEs,

\footnotetext{
${ }^{6}$ Central Bank of Bosnia and Herzegovina, Annual Report 2017., pp. 30.
} 
aimed at removing barriers and creating an enabling environment for their establishment and development. Effective policies must take into account all the specifics of $\mathrm{B} \& \mathrm{H}$. In this way it is possible to ensure sustainable economic development in which SMEs should be one of the pillars of creating a growing competitive economy.

As a consequence of de-industrialization in the post-war period, SMEs dominate the economies of the Western Balkans: SMEs make up about 99 per cent of businesses in all countries of the Western Balkans. On average, SMEs provide jobs for around three-quarters of the total number of employed, ranging from just below 70 per cent in Bosnia and Herzegovina to more than 80 per cent in Albania (Chart 2. a.) $)^{7}$.

At the same time, on average, SMEs add an estimated two- thirds of the countries' total annual value added, a proportion similar to the EU average, ranging from just above 50 per cent in Serbia to just below 70 per cent in Albania (Chart 2.b.).

Chart 2.
a) SMEs sector employment, share of total
b) SMEs sector value added, share of total

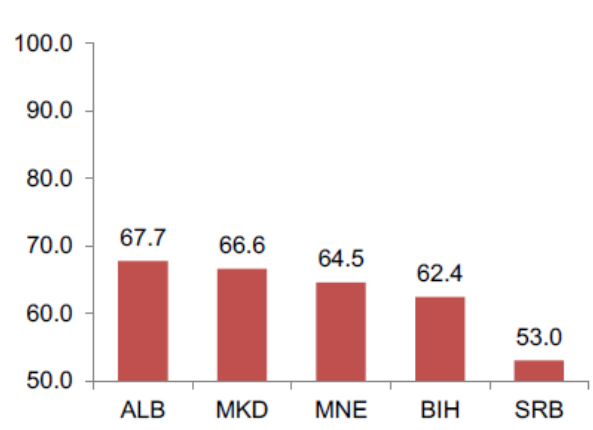
Source: OECD.

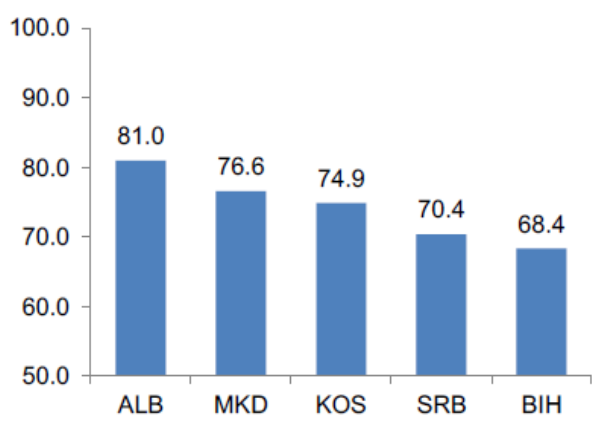
Source: OECD.

Productivity in the private sector lags well behind EU standards. The data highlight the labour productivity gap between Western Balkans countries and the EU-11. Chart 3.a. shows that, on average, aggregated firm level labour productivity in WB6 companies is about 60 per cent of that of the EU-11. Chart 3.b. demonstrates that this gap is driven by the manufacturing sector; the productivity of this sector in the WB-6 is around 55 per cent of that of the EU-11. In the WB-6 region, manufacturing is most productive in Serbia and Bosnia and Herzegovina, with both countries having a strong industrial basis. Services (wholesale, retail, transport, accommodation and food services) are more productive than manufacturing in all

\footnotetext{
${ }^{7}$ EBRD, The Western Balkans in transition: diagnosing the constraints on the path to a sustainable market economy, February 2018, pp.12.
} 
WB-6 countries, except in Albania, but still on average only 70 per cent of EU-11 levels. ${ }^{8}$

Chart 3.
a) Labour productivity, overall
b) Labour productivity by sectors

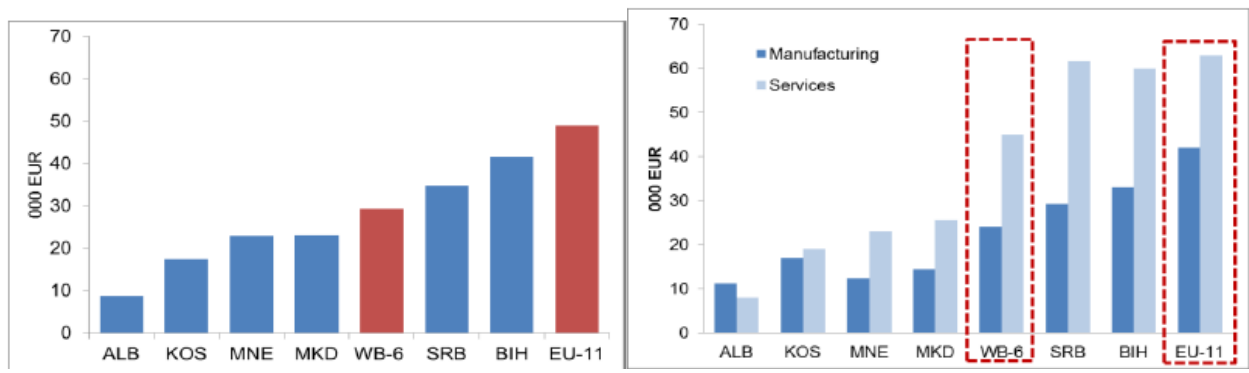

Source: OECD

\section{COMPETITIVENESS OF ECONOMY}

Competitiveness plays a key role in the economic development of modern economies that are highly integrated into the global economic system. The core of competitiveness are the most important: knowledge, infrastructure, technology and innovation. Modern approach to economic development and new theories that emerge in response to the problems of the economy are increasingly attributed to factors such as: a favorable macroeconomic context, cheap labor, abundant natural resources, economic policies and the promotion of development with the protection of industrial branches and the promotion of exports. The modern approach to economic growth and the development of demand is the answer to the question of how to ensure sustainable quality of life, the answer lies in sustainable competitiveness that is focused on enterprises and industry rather than the economy as a whole.

Competitiveness of the economy implies a sustainable growth of productivity and business operations, influenced by the macroeconomic and microeconomic, business environment as well. Competitiveness of the economy and social productivity determine the standard of living of the state or region and its inhabitants. The basis of competitiveness lies in the nature of the environment in which businesses operate, which means that the business environment should be stimulated, invested, transparently and efficiently in providing the necessary information, natural and human resources, physical infrastructure, financial resources, scientific, information and technology infrastructure.

\footnotetext{
${ }^{8}$ EBRD, The Western Balkans in transition: diagnosing the constraints on the path to a sustainable market economy, February 2018, pp.14.
} 
The ability of firms to achieve competitive advantages depends not only on their strategy, innovation, and business but also on external factors and institutions. Macroeconomic reforms are necessary, but not a sufficient prerequisite for increasing social productivity and competitiveness. Microeconomic reforms are also important, and they take place at the enterprise level. That is why joint action by government and business is needed to create an incentive-friendly environment. The process of improving competitiveness in $\mathrm{B} \& \mathrm{H}$ implies a partnership between governments, business and academia; all must work together on the challenges that the global market poses to $\mathrm{B} \& \mathrm{H}$.

According to research conducted by the World Economic Forum, the state of competitiveness of the economy of Bosnia and Herzegovina is bad. This assessment shows that much more needs to be done to achieve the average level of competitiveness in the near environment. A satisfactory level of country competitiveness is one of the conditions to be met for EU membership. Capacity needs to be built that will enable B\&H to face competition and the European Union market, which is a critical component of Copenhagen's economic criteria for EU accession.

According to the World Economic Forum (2017/2018), B\&H is ranked as 103rd and it is the most vulnerable of the countries of the Western Balkans. According to this report, Global Competitiveness Index for Serbia is 78, for Montenegro 77; for Albania 75, for Macedonia 68. On average, the GCI for the Western Balkans is 80, while the $11 \mathrm{EU}$ countries $^{9}$ have an index of 50 . This indicates a large gap between the Western Balkans and the EU 11.

The most problematic areas in the GCI:

- labour market efficiency related -capacity to attract talent from abroad and the "brain drain" problem,

- weak business sophistication, the reliance on informal (family and friend) relationships rather than on professional management,

- the lack of well-developed business clusters, and

- shallow value chains.

The largest difference in ranking between the WB-6 and EU-11 is in the areas of macroeconomic environment (particularly emphasising the challenging fiscal situation in the region compared with the EU-11), market size, business sophistication, infrastructure development, innovation capacity and labour market efficiency.

${ }^{9}$ The EU-11 refers to the 11 former socialist countries from central Europe, the Baltic states and south-eastern Europe that joined the EU in 2004 or since then, namely: Bulgaria, Croatia, the Czech Republic, Estonia, Hungary, Latvia, Lithuania, Poland, Romania, the Slovak Republic and Slovenia. 
The World Bank's annual Ease of Doing Business rankings vary widely in the region. FYR Macedonia is ranked at $11^{\text {th }}$ position out of 190 countries in the 2018 report, the highest ranking in the region and the second highest among all EBRD countries of operations. Kosovo, Montenegro and Serbia are ranked between 40th and 43rd position, Albania is 65 th, while Bosnia and Herzegovina is ranked the lowest in the region at 86 th position. ${ }^{10}$ Common problems across the region include dealing with construction permits and getting electricity.

Table 2. Ease of Doing Buseness, Rankings out, of 190, 2018.

\begin{tabular}{|c|c|c|c|c|c|c|c|c|c|c|c|}
\hline Economy & 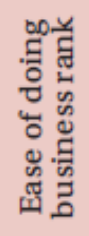 & 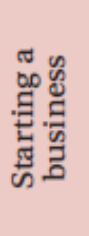 & 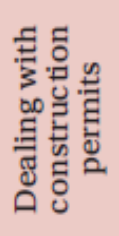 & 递 & 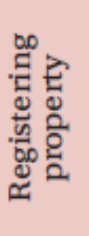 & 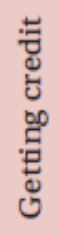 & 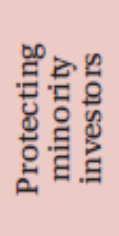 & 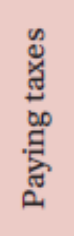 & 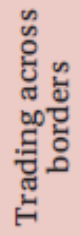 & 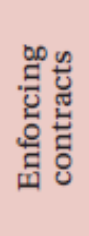 & 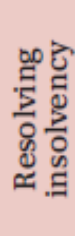 \\
\hline Albania & 65 & 45 & 106 & 157 & 103 & 42 & 20 & 125 & 24 & 120 & 41 \\
\hline $\mathrm{B} \& \mathrm{H}$ & 86 & 175 & 166 & 122 & 97 & 55 & 62 & 137 & 37 & 71 & 40 \\
\hline Macedonia & 11 & 22 & 26 & 53 & 48 & 12 & 4 & 29 & 27 & 35 & 30 \\
\hline Montenegro & 42 & 60 & 78 & 127 & 76 & 12 & 51 & 70 & 44 & 42 & 37 \\
\hline Serbia & 43 & 32 & 10 & 96 & 57 & 55 & 76 & 82 & 23 & 60 & 48 \\
\hline Kosovo & 40 & 10 & 122 & 106 & 34 & 12 & 89 & 45 & 48 & 49 & 49 \\
\hline
\end{tabular}

Source: World Bank Doing Business 2017 survey, http:/www.doingbusiness.org/Rankings.

\section{THE ROLE OF FOREIGN DIRECT INVESTMENT}

Bosnia and Herzegovina, as a small, still insufficiently developed country, has no special advantages over the country's environments or other destinations, which would be a strong motivation for entry of foreign investors. Infrastructure and communication are insufficiently developed, but these activities may be most interesting for foreign investors; they are the space in which the global strategy of foreign companies can be realized for mutual benefit. Although legal regulation provides sufficiently liberal status to foreign investors, the political and economic system has constraints on their entry. The general view is that the most important factor influencing foreign investment is domestic economic and political stability. The political and economic environment in $\mathrm{B} \& \mathrm{H}$ is disadvantageous, so the state and its overall policy, and in this context, and foreign investment policy, are the main determinants of the influence that foreign investments may have on economic development.

Foreign direct investment (FDI) in all Western Balkan countries has lagged well behind levels in the EU. Still, the region lags significantly behind the European Union in terms of FDI stock per capita received; average FDI stock per capita in

${ }^{10}$ Doing Business 2018, Reforming to create jobs, A World Bank Group Flagship Report 
the Western Balkans is around $€ 2,600$ while in the European Union it is around $€ 14,300 .{ }^{11}$ Even compared with the EU-11 average, the Western Balkans region's average FDI stock per capita is less than half that of the EU-11. However, over the past five years, Albania, Kosovo and Serbia have all experienced annual FDI inflows at a rate above the OECD average of 4.1 per cent of GDP, which is encouraging.

According to the data of the Central Bank of Bosnia and Herzegovina, the total direct foreign investment on 31 December 2017 amounts to 6.9 billion euros in B\&H. Within the UNCTAD Annual Report on Global FDI B\&H is ranked second in the Southeastern European countries. FDI for 2017. amounted to 397.6 million euros. Data for the period January-December 2017. indicate an increase in FDI by $37,9 \%$ in relation to the amount in 2016 . Or by $28,8 \%$ in comparison to the fiveyear average (2012-2016). Based on the forst preliminary data for period January Jun 2018. We can epect FDI to maintain a positive trend.

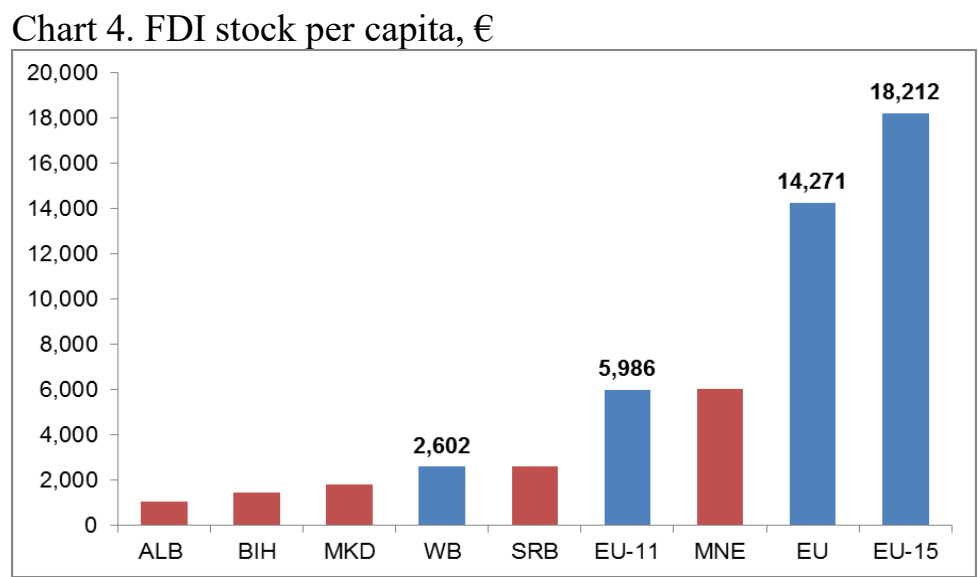

Source:The Western Balkans in transition: diagnosing the constraints on the path to a sustainable market economy, February 2018, pp. 39.

In $2007 \mathrm{~B} \& \mathrm{H}$ attracted 1.3 billion EUR which is absolutely the highest amount recorded till now, mainly thanks to the privatization of certain large state-owned enterprises. In 2008 FDI inflow (684 million EUR), without the expected privatization, can be considered as satisfied, especially if we take into account its positive structure (investment in production sector and high contribution of Greenfield investments). In 2009 the global economic crisis hit the inflow of FDI. Slight progress was achieved in 2010 and 2011. Unfortunately, despite promising expectations, foreign direct investment in 2012 and 2013 did not have a positive trend, mainly caused by slow economic recovery globally, which also reflected on ${ }^{11}$ EBRD, The Western Balkans in transition: diagnosing the constraints on the path to a
sustainable market economy, February 2018, pp 38 . 
investment worldwide. In 2017, with a $37.9 \%$ increase in foreign investment, the negative trend has stopped and we hope that investment growth will continue in the future.

Chart 5. Flow of FDI in Bosnia and Herzegovina, by years, million EUR

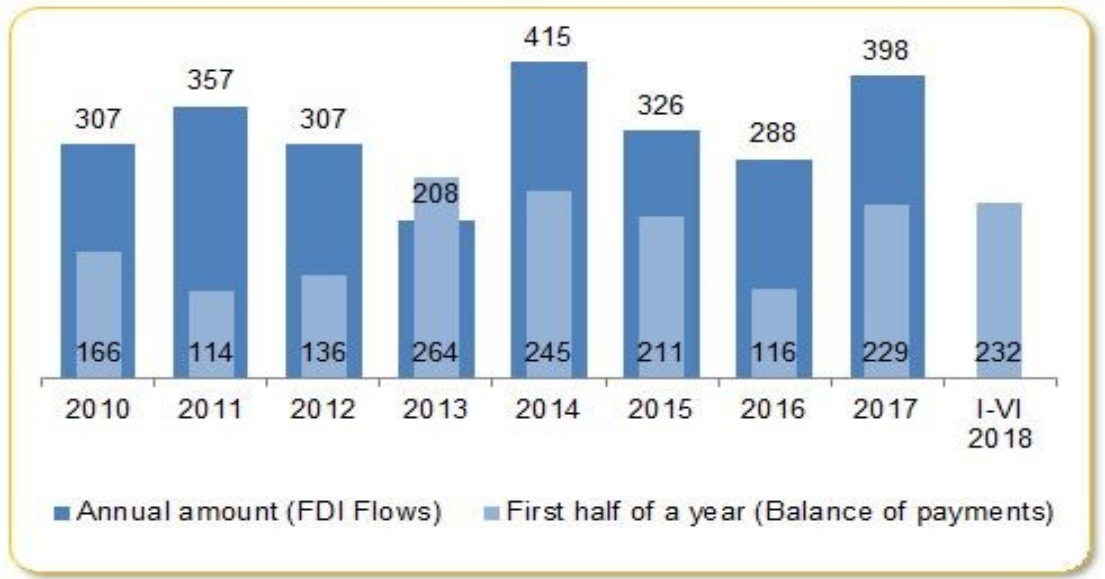

Source: Central Bank of B\&H (CBBH), 2007-2017 Flows of FDI, 2018.

Due to the good reputation and long industrial tradition of Bosnia and Herzegovina, the manufacturing sector received the largest amount of FDI (32\%). A significant share of investment has been in banking sector (26\%).

Chart 6. FDI Stocks by Industry, May 1994 - December 2017

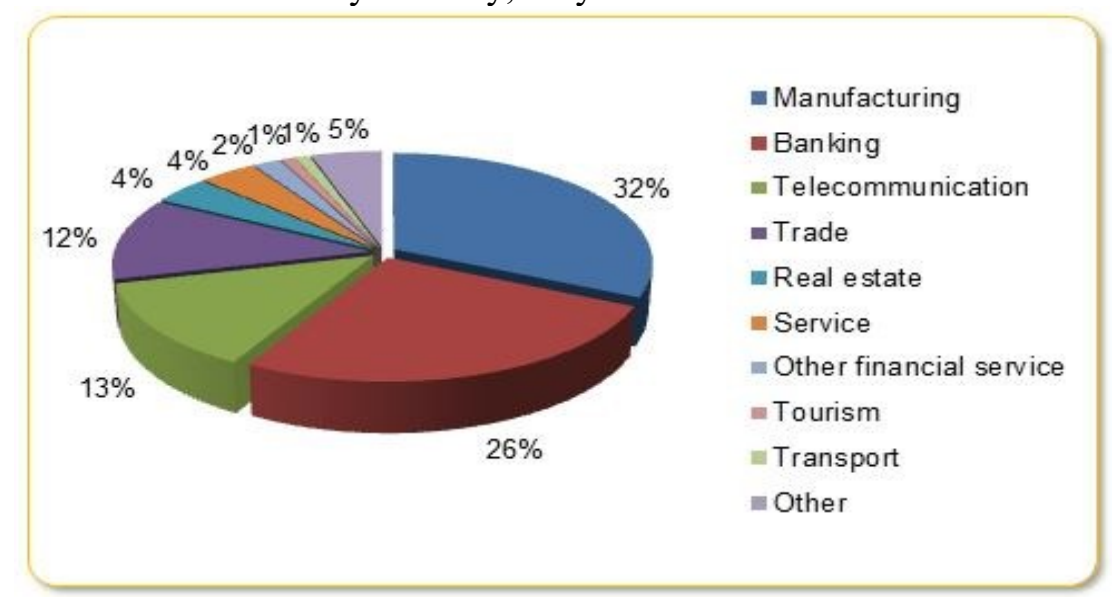

Source: Central Bank of B\&H

For example, the region's banking sector is owned largely by foreign investors, predominantly from the EU. The competitiveness of B\&H economy and its capacity to attract foreign direct investment depend on a number of factors, including the regulatoryenvironment, theskills base, the marketsize, the resource endowment, and 
the quality of its infrastructure and investment promotion efforts. The most important policies that affect FDI are: the FDI-specific legal framework, international investment agreements, business facilitation, the tax regime, labour policy and skills, and the competition regime.

\section{THE OPPORTUNITIES FOR GROWTH OF THE ECONOMY}

Bosnia and Herzegovina and Western Balkans countries lag behind EU standards, whether in terms of overall competitiveness, weak institutions and low standards of governance or barriers to trading across borders. However, the prospects for economic growth are positive, of course only assuming the planned structural reforms are achieved.. Bosnia and Herzegovina has maintained a stable 3 percent annual growth rate for the last few years. Growth in 2018 is projected at 3.2 percent, driven primarily by consumption. In the medium term, it is expected to pick up as structural reforms supported by new investment in infrastructure get underway. Real GDP growth is therefore projected to build gradually to 3.9 percent by 2020 .

The potential danger to realizing any projection may be delays in forming the new government after the October general election. Delay in forming new governments could slow reform efforts and drag down growth

Table 3. Movement of basic macroeconomic indicators shows moderate growth

\begin{tabular}{|l|r|r|r|r|r|r|r|}
\hline $\begin{array}{l}\text { Bosnia and } \\
\text { Herzegovina }\end{array}$ & 2014. & 2015. & 2016. & 2017. & $2018 . *$ & $2019 . *$ & $2020 .{ }^{*}$ \\
\hline Real GDP growth (\%) & 1,1 & 3,0 & 3,1 & 3,0 & 3,2 & 3,4 & 3,9 \\
\hline Consumption & n.a & n.a & n.a & 3,0 & 3,5 & 2,6 & 2,7 \\
\hline Investment & n.a & n.a & n.a & 0,6 & 0,8 & 1,0 & 0,8 \\
\hline Net exports & n.a & n.a & n.a & $-0,8$ & $-1,1$ & $-0,2$ & 0,4 \\
\hline $\begin{array}{l}\text { Consumer price } \\
\text { inflation (\%period } \\
\text { average) }\end{array}$ & $-0,9$ & $-1,0$ & $-1,6$ & 0,8 & 1,1 & 1,4 & 1,4 \\
\hline $\begin{array}{l}\text { Public revenues (\% of } \\
\text { GDP) }\end{array}$ & 44,2 & 43,2 & 43,1 & 43,7 & 44,5 & 42,9 & 42,7 \\
\hline $\begin{array}{l}\text { Public expenditure (\% } \\
\text { of GDP) }\end{array}$ & 46,2 & 42,5 & 42,1 & 41,4 & 45,0 & 42,6 & 41,5 \\
\hline
\end{tabular}

*World Bank estimates and projections

Source: World Bank Group, Western Balkans Regular Economic Report No.14, 2018, pp. 50. 
Table 4. suggests that $\mathrm{B} \& \mathrm{H}$ in the Western Balkans group achieved a somewhat higher growth rate than the average of the WB6 countries, and that growth will continue until 2020.

Table 4. Real GDP growth in Western Balkans, \%

\begin{tabular}{|l|r|r|r|r|r|r|r|}
\hline Real GDP growth (\%) & 2014. & 2015. & 2016. & 2017. & $2018 . *$ & $2019 . *$ & $2020 . *$ \\
\hline Albania & 1,8 & 2,2 & 3,4 & 3,8 & 4,0 & 3,6 & 3,5 \\
\hline Bosnia and Herzegovina & 1,1 & 3,0 & 3,1 & 3,0 & 3,2 & 3,4 & 3,9 \\
\hline Kosovo & 1,2 & 4,1 & 4,1 & 3,7 & 4,0 & 4,5 & 4,5 \\
\hline Macedonia, FRY & 3,6 & 3,9 & 2,9 & 0,0 & 2,5 & 2,9 & 3,2 \\
\hline Montenegro & 1,8 & 3,4 & 2,9 & 4,3 & 3,8 & 2,8 & 2,5 \\
\hline Serbia & $-1,8$ & 0,8 & 2,8 & 1,9 & 3,5 & 3,5 & 4,0 \\
\hline WB6 & 0,3 & 2,2 & 3,1 & 2,4 & 3,5 & 3,5 & 3,8 \\
\hline
\end{tabular}

*World Bank estimates and projections

In 2017, the labor market in the EU countries registered lower unemployment rates compared to 2016. The average unemployment rate in the EU 28 has been the lowest since 2009 and gradually reaches the level just before the economic crisis (in 2008 it was $7 \%$ ). The unemployment rate in $\mathrm{B} \& \mathrm{H}$ was $20,5 \%$ in 2017 . And it is lower in relation to 2016 . by $4,9 \%$, continuing the downward trend. ${ }^{12}$ However, it is evident that the unemployment rate in $\mathrm{B} \& \mathrm{H}$ remains one of the largest in the region. The problem of high unemployment in B\&H can only be solved by the implementation of the necessary reforms, which ultimately should lead to convergence of the economy towards EU economies. To achieve this goal it is necessary to reform the education system with the aim of establishing stronger links with the labor market. The reform sholud include support for first-job seekers, with active discouragement of work in the informal economy, and a significant reduction in social security contributions.

Reform means to protect workers' rights in accordance with the standards of the ILO and the EU directives on the work. The reform of social security and pensions Social protection systems should involve the protection and increase social assistance to those who need.

\section{CONCLUSION}

The long-term and sustainable development of Bosnia and Herzegovina depends in a large extent on the success of the entry into the Western European market because the country is heavily dependent on exports, especially in the European Union countries. That is why building up national competitive advantages is the only way to overcome this obstacle; the growth of the competitiveness of local businesses creates the preconditions for entering the European and world markets.

${ }^{12}$ CBB\&H, Annual Report for 2017., 2018. 
Integration of the economy into the $\mathrm{EU}$ creates conditions for the internationalization of economic activities and the arrival of foreign investors, which, with the establishment of new enterprises or by taking local ones, significantly affect the quality and volume of employment as well as the growth of competitiveness of the economy at the international level. To close the gap with advanced Europe faster, B\&H need stronger policies to improve labor supply, boost investment, and increase efficiency.

European Union through the strategic objectives (Europe 2020) put a smart, sustainable and inclusive growth at the center of its activities, with five main objectives (employment, research and development, climate change and energy, education and the fight against corruption). Given the high degree of integration with the EU economy, the immediate growth prospects are in part beyond the direct control of their respective governments, as economic recovery to a large extent depend on future growth in the European Union. At the same time, FDI is unlikely to return in larger amounts soon, since privatization opportunities have been mostly exhausted, while FDI at the global level has not yet fully recovered.

From today's perspective it may be possible to grow faster, smarter and better, but the B\&H will need to radically change economic development strategy at both the regional and national level. However, the key instruments for achieving the objectives of the SEE 2020 Strategy and for resolving the crucial economic problems are in the hands of the national governments, that need to devise their own development strategies in line with specific priorities. After election, this may be a key challenge for the new government in $\mathrm{B} \& \mathrm{H}$.

In view of the extreme deindustrialization that has taken place in the region, the new growth model has to ensure one common objective: the strengthening of the real sector of the $\mathrm{B} \& \mathrm{H}$ economy, as this is a crucial element for improving export performance and increasing competitiveness on global markets. This will require a more targeted industrial policy that would strengthen key manufacturing industries, stimulate diversification and upgrading of the industrial base and facilitate reindustrialization. The reindustrialization of the $\mathrm{B} \& \mathrm{H}$ would be in line with recent EU objectives that aim at increasing the share of manufacturing value added from 15 per cent to 20 per cent of GDP by 2020 .

It is necessary to implement structural reforms that will result in:

- stimulating production, trade, financial flows,

- reforming the labor market and the public sector,

- that is why growth of investment and exports is the main determinant of long-term growth,

- significant convergence towards EU living standards requires a major and sustained boost to productivity and investment. 
The ability to turn adjustment of the economy is reflected in the speed with which the economy responds to changing market conditions and recognize new possibilities and opportunities that can not be covered by one macroeconomic indicator.

\section{REFERENCES}

1. Annual Report for 2017. Central Bank of Bosnia and Herzegovina, June, 2018.

2. Bosnia And Herzegovina Economic Reforme Programme 2016-2018 (ERP B\&H 2016-2018), Sarajevo, January 2016.

3. Bosnia aand Herzegovina- Annual Report 2017., Council of Ministers, B\&H

4. Barro, R. and X. Sala-I-Martin, 1992. Convergence. Journal of Political Economy

5. Bosnia And Herzegovina Outlook 2015- 2018, Spring 2015, Council of Ministers

6. Competitiveness in South East Europe A POLICY OUTLOOK 2018, Competitiveness and Private Sector Development, OECD,

7. Doing Business 2016, Measuring Regulatory Quality and Efficiency, Economic Profile 2016. Bosnia and Herzegovina, A World Bank Group Flagship Report,

8. Doing Business 2018, Reforming to Create Jobs, Economic Profile of Bosna and Herzegovina, A World Bank Group

9. EBRD, Transition Report 2012 Inegration across Borders, 2012.

10. EBRD, The Western Balkans in transition: diagnosing the constraints on the path to a sustainable market economy, February 2018.

11. EBRD, Transition Report 2017-18.

12. Globalization and Development: an International business strategy approach, Transnational Corporations, Vol.15.No.1 2006.

13. Hansen,, W. Michael, Theories of Transnational Corporations, Environment and Development, Copenhagen Business School, Institute for Intercultural ommunication and Menagement, 2010.

14. Icentives and Investments: Evidence and Policy Implications, Investment Climate Advisory Services of the World Bank Group, December 2009.

15. Investments Incentives, Growing use, uncertain benefits, uneven controls, An exploration of government measures to attract investments, GSI, 2007.

16. South East Europe regular Economic Report, No.3. From Double-Dip Recession to Accelerated Reforms, December, 18.2012., Povetry Reduction and Economic management Unit Europe and Central Asia, The World Bank

17. South East Europe regular Economic Report, No.4. From Double-Dip Recession to Fragile Recovery, June 18. 2013., Povetry Reduction and Economic management Unit Europe and Central Asia, The World Bank

18. South East Europe 2020: Annual Report On Implementation For 2017, July 2017. 
19. South East Europe, Regular Economic Report, No. 10, Resilient Growth and Rising Risks, Faall 2016. The World Bank

20. Strategic Framework for B\&H, Council of Ministers, Sarajevo, August 2015.

21. The Western Balkans in transition: diagnosing the constraints on the path to a sustainable market economy By Peter Sanfey and Jakov Milatovic February 2018, EBRD

22. The Global Competitiveness Report, 2015-2016., 2017-2018. World Economic Forum, Geneva

23. UNCTAD, World Investment Report 2012.; Towards a New Generation of Investment Policies

24. UNCTAD, World Investment Report 2015: Reforming International Investment Governance

25. World Bank Group, Western Balkans Labour Market trends 2018., The Vienna Institute for International Economic Studies

26. World Bank Group, Western Balkans Regular Economic Report: Vulnerabilities Slow Growth, No. 13. Spring 2018

27. www. Europa.eu 